\title{
Local Anesthetics: Use and Effects in Autologous Fat Grafting
}

\author{
Girard AC*, Festy F and Roche R \\ ADIP'SCULPT, Platform CYROI, 2 rue Maxime Rivière, 97490 Sainte Clotilde, Reunion Island, France
}

\begin{abstract}
Autologous fat grafting has been used for over a century and is considered as a technique of choice for soft tissue filling in plastic and reconstructive surgery. However, the critical point of this technique is fat graft survival. In order to assure best efficiency of adipose grafts, new techniques and procedures have been optimized in order to avoid graft resorption and thus, to improve graft survival. Among the steps involved in lipofilling process, some researchers and surgeons have inter alia focused on the effects of local anaesthetics on adipose graft.
\end{abstract}

After an overview on the different local anaesthetics commonly used and their mode of action, this review focuses on the effects of these drugs on non-neuronal cells with special emphasis on adipose tissue and adipose-derived stem cells. Moreover, while there is no consensus on the best way how to handle adipose tissue prior to its injection, this review describes how to get rid of the adverse effects of local anaesthetics.

Keywords: Autologous fat grafting; Liposuction; Local anaesthetics; Lidocaine; Adipose-derived stem cells

Abbreviations: AFG: Autologous Fat Grafting; LA: Local Anaesthetic; ADSC: Adipose-Derived Stem Cell

\section{Introduction}

Because of its easy access by liposuction and due to the fact that it contains many progenitor cells, subcutaneous adipose tissue is a tissue of choice for soft tissue filling in cosmetic and reconstructive surgery. Autologous Fat Grafting (AFG), or lipofilling, has been used for over a century and represents a safe technique for soft tissue filling [1-3]. However, although the technique has seen marked improvements over time, surgeons are still facing graft resorption that often requires overcorrection of the treated area or other interventions so that the aesthetic result is in line with expectations of the patient $[2,4]$. Thus, new processes have been developed in order to increase the rate of engraftment by promoting cell survival within the graft [5]. Among the critical points that may impair adipose graft retention and survival, Local Anesthetics (LAs) have been investigated. Even under general anesthesia, LAs are often infiltrated at the fat donor site (generally through a tumescent solution with epinephrine for vasoconstriction) and can also be delivered at the injection site to ensure patient comfort.

Further studies in the context of autologous fat grafting in plastic surgery have allowed to highlight LAs adverse effects but controversies remain regarding their substantial impact on fat graft survival [611]. Although this confusion remains among all LAs, lidocaine is the most commonly used LA for liposuction procedure and is thereby the best described in this context. However, this drug has also been so far neglected in terms of recommendations for dosage.

Thus, through the literature, local anesthesia use and effects in AFG are described herein.

\section{From adipose tissue to soft tissue filling}

Adipose tissue is first and foremost an organ of lipid storage. It represents the main body's energy reserve, involving lipids as the main fuel for adult humans. Adipose tissue is also considered as a true endocrine organ where the adipocyte lies at the heart of this system by participating in the regulation of energy homeostasis in the body [12].

While mature adipocytes constitute the specialized cells of adipose tissue, stocking triglycerides in a huge lipid droplet inside their cytoplasm, other cell types are included in adipose environment [13]. Beside mature adipocytes surrounded by conjunctive tissue with collagene fibers, the Stromal Vascular Fraction (SVF) includes preadipocytes, endothelial cells, smooth muscle cells, blood cells (from blood vessels) and Adipose-Derived Stem Cells (ADSCs), that have been discovered not so far ago $[14,15]$. These ADSCs share similar properties with mesenchymal stem cells: quite similar phenotype, ability to proliferate and to differentiate into mesenchymal cell types such as adipocytes [15-17], chondrocytes [18-22], osteoblasts [15,18,23$26]$, tenocytes [27,28], myocytes [15,28,29]. But their differentiation potential is not restricted to mesodermal lineage: ADSCs have been shown to trans differentiate into other cell types, including endothelial cells $[28,30]$ and neuronal-type cells $[28,31]$. Besides differentiation, ADSCs can also secrete numerous paracrine factors (like cytokines, growth factors, anti-apoptotic factors) that would strongly support tissue regeneration $[30,32]$.

Owing to their high potential for tissue regeneration and their easy access by simple liposuction, ADSCs are subject to special attention and are already used in regenerative medicine (many clinical trials ongoing) [33]. Plastic surgeons also pay attention to these cells as they exhibit special functions that may improve fat graft survival and efficiency [34-40]. Indeed, these ADSCs are known to be able to differentiate into mature adipocytes, which may contribute to face fat graft resorption and maintain the desired volume for soft tissue repair or augmentation. Moreover, there is increasing evidence that ADSCs contribute to vascularization of adipose grafts, thus improving cell survival inside the grafts [38,41-43]. For all that considerations, the technique of cell-assisted lipotransfer has emerged: it consists in ADSCs enrichment of autologous fat prior to its injection [37,38]. However regulations regarding the use of stem cells in plastic surgery differ between countries and this practice is not legally approved everywhere. Further clinical studies must be performed to assure patient safety and efficiency of such procedures [39].

Thus, containing many different types of cells (voluminous

*Corresponding author: Girard AC, ADIP'SCULPT, Platform CYROI, 2 rue Maxime Rivière, 97490 Sainte Clotilde, Reunion Island, France, Tel: +262 262938 840; Fax: +33 176620 781; E-mail: ac.girard@adipsculpt.com

Received June 11, 2013; Accepted August 22, 2013; Published August 29, 2013

Citation: Girard AC, Festy F, Roche R (2013) Local Anesthetics: Use and Effects in Autologous fat Grafting. Surgery Curr Res 3: 142. doi:10.4172/2161-1076.1000142

Copyright: $\odot 2013$ Girard AC, et al. This is an open-access article distributed under the terms of the Creative Commons Attribution License, which permits unrestricted use, distribution, and reproduction in any medium, provided the original author and source are credited. 
adipocytes, stromal cells) and being easily accessible, adipose tissue has been shown to be a great filler and is now commonly used to fill soft tissues and restore volume. Lipofilling has now gained popularity, especially with the development of liposuction technique and also thanks to abundance and availability of subcutaneous fat in the human body. Beside its role as a secretory and endocrine organ, adipose tissue is used to correct soft tissue defects as well as facial rejuvenation, body contouring, or other numerous applications, both for aesthetic and reconstructive purposes $[32,34]$.

\section{Autologous fat grafting and the tumescent technique for liposuction}

Autologous fat transfer has been subject to great evolution over the last century. Conceived by Fisher and Fisher, liposuction first appeared as a revolutionary technique in 1974 [44]. Then, Klein invented the tumescent liposuction which consists of infiltrating at the sampling zone a local anesthetic and a vasoconstrictor diluted in a large volume of fluid (saline type) [45]. Usually, the volume of tumescent solution is almost equal to the volume of adipose tissue to be removed. This technique allowed the patients to benefit from liposuction totally by local anesthesia, thus avoiding the risks of general anesthesia and promoting a short recovery time. This also allowed the use of much smaller cannulas and practice of superficial liposuction, only 3-4 $\mathrm{mm}$ deep subcutaneous [46]. Patients no longer had to fear excessive bleeding and undesirable skin depressions. In addition, liposuction by cannulation did not seem to damage the adipocytes. Then in the mid80 s, plastic surgeons began to inject the fat obtained by liposuction $[47,48]$.

With invention of the innovative technique of tumescent liposuction by Klein, lidocaine systemic toxicity has been significantly reduced: dilution of lidocaine in a large volume of normal saline significantly decreased systemic absorption rate of the drug $[45,49,50]$.
Tumescent anesthesia finally offers many advantages, among which: decreased LA absorption at the infiltrated donor site, increased patient comfort after surgery due to a longer lasting effect of LA, decreased and delayed systemic absorption and lower peak blood plasma levels (thus, avoiding toxic potential like cardiotoxicity or central nervous system toxicity) [51]. Moreover, even if LA infiltration at the fat donor site can allow avoiding general anesthesia and its related risks, tumescent liposuction with local anesthesia is currently mixed with general anesthesia in order to assure post-operative patient comfort. Despite recorded patient safety with tumescent anesthesia, questions remain about LAs effect in AFG.

\section{Local anesthetics: classes and mode of action}

Local anesthetics act by blocking sodium ionic channels involved in neural impulse conduction, thus avoiding peri- and post-operative pain [52,53]. These cocaine-derived substances have been discovered more than a century ago, and are divided in two distinct chemical families: amino esters (tetracaine, procaine...) and amino amides (lidocaine, bupivacaine, ropivacaine) (Table 1). Compared to amino esters, amino amides may cause rare allergies.

Lidocaine was the first amino amide-type LA synthesized by Löfgren [54]. This LA presents a rapid onset and an intermediate duration of action. Through the years, other LAs have been discovered in order to improve duration of action and decrease toxicity risk when possible (Table 1). Although lidocaine is the oldest aminoamide LA, this drug is widely used all over the world and seems to be the most appropriate in the context of liposuction and autologous fat transfer [45].

LA potency is partly due to their lipid solubility: LAs have a lipophilic chemical group (comprising benzene ring or thiophene ring for articaine) that allows them to diffuse across plasma membrane and

\begin{tabular}{|c|c|c|c|c|c|c|c|c|c|c|}
\hline $\begin{array}{c}\text { Classification and } \\
\text { name }\end{array}$ & $\begin{array}{c}\text { Date of } \\
\text { discovery }\end{array}$ & $\begin{array}{l}\text { pKa } \\
\left(25^{\circ} \mathrm{C}\right.\end{array}$ & Metabolism & $\begin{array}{l}\text { Onset } \\
(\mathrm{min})\end{array}$ & $\begin{array}{l}\text { Duration of action } \\
\text { (min) }\end{array}$ & $\begin{array}{l}\text { Relative } \\
\text { potency }\end{array}$ & $\begin{array}{l}\text { Maximal dose } \\
\text { (for adults) }\end{array}$ & $\begin{array}{c}\text { Maximal } \\
\text { dose with } \\
\text { epinephrine }\end{array}$ & $\begin{array}{l}\text { Dose for } \\
\text { tumescent } \\
\text { anesthesia }\end{array}$ & $\begin{array}{l}\text { Relative } \\
\text { toxicity }\end{array}$ \\
\hline \multicolumn{11}{|l|}{ Amino esters } \\
\hline Procaine & 1905 & 9 & $\begin{array}{l}\text { Plasma } \\
\text { esterases }\end{array}$ & $\begin{array}{c}\text { Slow } \\
(10-20)\end{array}$ & $\begin{array}{l}\text { Short } \\
(15-60)\end{array}$ & 1 & $\begin{array}{c}500 \mathrm{mg} \\
(7 \mathrm{mg} / \mathrm{kg})\end{array}$ & - & - & 1 \\
\hline Chloroprocaine & 1952 & 9.3 & $\begin{array}{l}\text { Plasma } \\
\text { esterases }\end{array}$ & $\begin{array}{l}\text { Fast } \\
\text { (5) }\end{array}$ & $\begin{array}{l}\text { Short } \\
(15-45)\end{array}$ & 1 & $\begin{array}{c}600 \mathrm{mg} \\
(8 \mathrm{mg} / \mathrm{kg})\end{array}$ & - & - & 9 \\
\hline Tetracaine & 1928 & 8.6 & $\begin{array}{l}\text { Plasma } \\
\text { esterases }\end{array}$ & $\begin{array}{l}\text { Slow } \\
\text { (15) }\end{array}$ & $\begin{array}{c}\text { Intermediate } \\
(60-200)\end{array}$ & $>4$ & $\begin{array}{c}100 \mathrm{mg} \\
(1.5 \mathrm{mg} / \mathrm{kg})\end{array}$ & - & - & 4.1 \\
\hline \multicolumn{11}{|l|}{ Amino amides } \\
\hline Lidocaine & 1943 & 7.9 & Liver & $\begin{array}{l}\text { Fast } \\
(2-5)\end{array}$ & $\begin{array}{c}\text { Intermediate } \\
(60-120) \text { Longer with } \\
\text { epinephrine }\end{array}$ & 4 & $\begin{array}{c}200-300 \mathrm{mg} \\
(5 \mathrm{mg} / \mathrm{kg})\end{array}$ & $\begin{array}{c}500 \mathrm{mg} \\
(7 \mathrm{mg} / \mathrm{kg})\end{array}$ & $30-35 \mathrm{mg} / \mathrm{kg}$ & 2 \\
\hline Prilocaine & 1960 & 7.9 & $\begin{array}{l}\text { Lung } \\
\text { Kidney } \\
\text { Liver }\end{array}$ & $\begin{array}{l}\text { Fast } \\
(2-5)\end{array}$ & $\begin{array}{l}\text { Intermediate } \\
(30-90)\end{array}$ & 4 & $\begin{array}{c}500 \mathrm{mg} \\
(7 \mathrm{mg} / \mathrm{kg})\end{array}$ & $\begin{array}{c}600 \mathrm{mg} \\
(8 \mathrm{mg} / \mathrm{kg})\end{array}$ & $15 \mathrm{mg} / \mathrm{kg}$ & 1.8 \\
\hline Articaine & 1969 & 7.8 & $\begin{array}{c}\text { Liver } \\
\text { Serum } \\
\text { esterases }\end{array}$ & $\begin{array}{l}\text { Fast } \\
(2-3)\end{array}$ & $\begin{array}{l}\text { Intermediate } \\
(60-180)\end{array}$ & 5 & $7 \mathrm{mg} / \mathrm{kg}$ & $7 \mathrm{mg} / \mathrm{kg}$ & $35 \mathrm{mg} / \mathrm{kg}$ & 1.5 \\
\hline Mepivacaine & 1956 & 7.9 & Liver & $\begin{array}{l}\text { Fast } \\
(3-5)\end{array}$ & $\begin{array}{c}\text { Intermediate } \\
(45-90)\end{array}$ & 4 & $\begin{array}{c}300 \mathrm{mg} \\
(5 \mathrm{mg} / \mathrm{kg})\end{array}$ & $(5 \mathrm{mg} / \mathrm{kg})$ & - & 2.2 \\
\hline Bupivacaine & 1963 & 8.1 & Liver & $\begin{array}{c}\text { Slow } \\
(10-15)\end{array}$ & $\begin{array}{l}\text { Long } \\
(200+) \text { Longer with } \\
\text { epinephrine }\end{array}$ & 16 & $\begin{array}{c}175 \mathrm{mg} \\
(2.5 \mathrm{mg} / \mathrm{kg})\end{array}$ & $\begin{array}{c}225 \mathrm{mg} \\
(3 \mathrm{mg} / \mathrm{kg})\end{array}$ & - & 8 \\
\hline Levobupivacaine & 1960's & 8.1 & Liver & $\begin{array}{c}\text { Slow } \\
(10-15)\end{array}$ & $\begin{array}{l}\text { Long } \\
(200+)\end{array}$ & 16 & $\begin{array}{c}175 \mathrm{mg} \\
(2.5 \mathrm{mg} / \mathrm{kg})\end{array}$ & - & - & $<8$ \\
\hline Ropivacaine & 1950's & 8.1 & Liver & $\begin{array}{c}\text { Slow } \\
(5-15)\end{array}$ & $\begin{array}{l}\text { Long } \\
(200+)\end{array}$ & 16 & $\begin{array}{c}188 \mathrm{mg} \\
(2.5-3 \mathrm{mg} / \mathrm{kg})\end{array}$ & - & - & 7 \\
\hline
\end{tabular}

Data from $[54,83,84]$ 
enter neural cells to reach the inner part of voltage-dependent channels and block them [53,54]. Due to their liposolubility potential, LAs are also known to diffuse in adipose tissue, in the case of tumescent anesthesia for liposuction [55].

Moreover, the use of a vasoconstrictor as epinephrine (adrenaline) provides potentialization of LAs, providing increased long-lasting action [56]. Indeed, epinephrine is used to decrease bleeding and also slows the passage of LAs in systemic circulation, thus ensuring prolonged retention in the tissue.

\section{Currently used LAs in AFG}

Maximum recommended doses of LAs are confused. For lidocaine injection, they are estimated at $200 \mathrm{mg}$ [57]; for tumescent lidocaine, estimation is $30 \mathrm{mg} / \mathrm{kg}$ for the French Society of Anesthesia and Intensive Care ("Société française d'anesthésie et de réanimation", SFAR), and safe limit dose is estimated at $35 \mathrm{mg} / \mathrm{kg}$ by Klein [49] who has also reached highest dose of $50 \mathrm{mg} / \mathrm{kg}$ in tumescent anesthesia [58]. LA dose for tumescent anesthesia $(30-35 \mathrm{mg} / \mathrm{kg})$ is finally much higher than recommended dose for injection $(5-7 \mathrm{mg} / \mathrm{kg})$. This is explained by the fact that 1) LAs are lipid soluble so they may preferentially diffuse into fat; 2) adipose tissue is not much vascularized; 3 ) supplementation with vasoconstrictor delays plasma diffusion [45,51].

For other LAs like ropivacaine, bupivacaine and levo-bupivacaine, and due to their higher relative potency and their potential higher systemic toxicity (Table 1), doses could be 10 fold less compared to lidocaine $[59,60]$. The use of long-acting LAs as bupivacaine may offer interesting postoperative analgesia [61] but these drugs are poorly referenced in the context of fat grafting, in which appropriate doses and effects are not well known. This is the same lack of knowledge regarding prilocaine, which has also been used for tumescent anesthesia (maximal dose of $15 \mathrm{mg} / \mathrm{kg}$ for safe liposuction) [62].

Ultimately, the most currently used LA for liposuction and AFG is lidocaine and that's on this molecule that literature is the most abundant. Indeed, a survey from the American Society for Aesthetic Plastic Surgery concluded that: for adipose tissue harvest, $40 \%$ of surgeons use tumescent solution containing $50 \mathrm{~mL}$ of $1 \%$ xylocaine +1 $\mathrm{mL}$ epinephrine 1:1000 in $1 \mathrm{~L}$ normal saline, which corresponds to 0.5 $\mathrm{mg} / \mathrm{mL}$ of lidocaine. Then, about $30 \%$ of them use a mixture of $0.5 \%$ xylocaine with epinephrine and $22 \%$ use $1 \%$ xylocaine epinephrine mixture. The remaining $8 \%$ of American physicians use epinephrine alone or other solution [63].

Among other solutions, articaine, which is widely used in dentistry, has also been reported to be an efficient LA for tumescent liposuction [64,65]. With dose of $0.4 \mathrm{mg} / \mathrm{mL}$ articaine combined with $1 \mu \mathrm{g} / \mathrm{mL}$ epinephrine, this tumescent solution presents high anesthetic potency (due to high lipid solubility that improves cell membrane diffusion), and also presents low systemic toxicity (because of easy and rapid metabolism by esterases) [64].

Moreover, regarding site of injection of adipose tissue, $80 \%$ of plastic surgeons use either 0.5 or $1 \%$ xylocaine with epinephrine. Other solutions may be used but finest fat injections in small areas also allow to avoid the use of local anesthesia at the site of injection [63].

To some extent, regarding systemic toxicity and duration of action in the context of liposuction and fat grafting, there is no reason to use another anesthetic as lidocaine [45,66]. Indeed, for this kind of procedure, a tumescent solution containing lidocaine plus epinephrine (at recommended doses) is sufficient, efficient, and present almost no risk of local anesthesia complication.

\section{Cytotoxicity of LAs in non-neuronal cells}

LA toxicity in neuronal cells has already been reported [67]. Furthermore, as described above and aside from patient allergies, systemic toxicity of LAs is quite rare, particularly in the context of tumescent liposuction. Even for face surgery, where areas are well vascularized and highly innerved, this toxicity can be easily managed by respecting the recommended doses for LA injection.

However, to a lesser extent in terms of serious medical risk, LAs have been shown to exert cytotoxic effects in many non-neuronal cells, including fibroblasts [68], chondrocytes [69] and myoblast cells [70]. Considering LAs adverse effects in many cell types, their use is therefore more cautious in some clinical applications. This is the case of intra-articular injections following joint surgery, where LAs (mostly lidocaine, bupivacaine or ropivacaine) exert cytotoxic effects on chondrocytes and thus, may contribute to cartilage degeneration [69,71]. Some studies now recommend to avoid intra-articular administration of LA or to find alternatives [72]. Publication of several case reports about postoperative chondrolysis have finally alerted orthopedic surgeons and anesthetists who now pay more attention on these severe and disabling complications that can be partly due to LAs [73].

By the same, it is now time to consider LAs effects in the context of lipofilling. Concerning LAs effects in adipose tissue cells, the debate is still relevant. Overall related studies are reported in Table 2.

Finally, only few studies exist on LA effects in AFG and the methods used are all different, which may explain the different and socalled "controversial" results. Indeed, most of the studies are made in vitro and include sometimes high doses, and other times minor doses of LA. Moreover, as there is no standardized protocols, adipose tissue harvest and processing are also involved in these differences between studies, as well as type of cells studied, in culture or not (Table 2). Thus, it is difficult to really compare all these studies.

From our own studies, we have shown that clinical doses of lidocaine (ranging from 0.4 to $1.6 \mathrm{mg} / \mathrm{mL}$ ) could affect cultured ADSC viability in a dose and time dependent manner [10]. However, this cytotoxicity could be partially prevented by washing the cells after lidocaine incubation. Thus, depending on the dose, duration of action, and also procedure of adipose tissue handling (like centrifugation and washing that may remove LAs and avoid their deleterious effects) LAs can cause more or less harmful effects on the cells within the graft. Similarly, Keck et al. have shown that LAs impair preadipocyte viability and their differentiation into mature adipocyte $[7,8]$. Finally, our results were confirmed in an in vivo study of fat transfer into immunodeficient mice (Table 2) [74,75].

Actually, the different conclusions made in all these studies are dependent on the method used for adipose tissue handling prior to injection, insofar as centrifuging and washing adipose tissue must allow removing most of the drugs present from liposuction.

Moreover, regarding the use of epinephrine for vasoconstriction, the low doses that are currently used (usually $1 \mu \mathrm{g} / \mathrm{mL}$ ) seem to be safe for the patient and do not influence adipose-derived stem cell viability [10]. Therefore, epinephrine can be used in liposuction procedure for AFG.

Knowing the importance of ADSCs for fat graft survival [38$40,42,43]$, the potential impact of LAs on these cells has to be considered in the context of AFG. Indeed, as mentioned here above, ADSCs properties may be of great interest for fat graft retention and efficiency, 
Citation: Girard AC, Festy F, Roche R (2013) Local Anesthetics: Use and Effects in Autologous fat Grafting. Surgery Curr Res 3: 142. doi:10.4172/21611076.1000142

\begin{tabular}{|c|c|c|c|c|c|}
\hline Reference & LAs & $\begin{array}{l}\text { Type of } \\
\text { study }\end{array}$ & $\begin{array}{l}\text { Tissue or cell type and } \\
\text { origin }\end{array}$ & $\begin{array}{l}\text { LA effects on adipose tissue, } \\
\text { adipose-derived stem cells and fat } \\
\text { grafting }\end{array}$ & Comments \\
\hline $\begin{array}{l}\text { Moore et al. } \\
1995 \text { [85] }\end{array}$ & Lidocaine & In vitro & $\begin{array}{l}\text { Adipocytes from human } \\
\text { suction lipectomy, after } \\
\text { collagenase digestion }\end{array}$ & $\begin{array}{l}\text { Lidocaine potently inhibits glucose } \\
\text { transport and lipolysis in adipocytes } \\
\text { and their growth in culture } \\
\text { But adipocytes regain their function } \\
\text { after washing }\end{array}$ & $\begin{array}{l}\text { This study introduces the impact of LAs in AFG } \\
\text { and proposes washing as an interesting method } \\
\text { to erase LA adverse effects }\end{array}$ \\
\hline $\begin{array}{l}\text { Large et al. } \\
1997[86]\end{array}$ & Lidocaine & In vitro & $\begin{array}{l}\text { Subcutaneous fat cells } \\
\text { from obese patients }\end{array}$ & $\begin{array}{l}\text { Compared to general anesthesia, } \\
\text { local anesthesia does not influence } \\
\text { adrenergic regulation of lipolysis }\end{array}$ & $\begin{array}{l}\text { This study is more related to obesity (adipose } \\
\text { tissue harvest during clinical studies) }\end{array}$ \\
\hline $\begin{array}{l}\text { Sommer } \\
\text { and Sattler } \\
(2000)[11]\end{array}$ & - & Review & $\begin{array}{l}\text { Comparative studies } \\
\text { (human, animal and in } \\
\text { vitro studies) on graft } \\
\text { survival and longevity }\end{array}$ & $\begin{array}{l}\text { Review of literature shows similar } \\
\text { survival rates of fat grafts after either } \\
\text { general or local anesthesia }\end{array}$ & $\begin{array}{l}\text { This review does not focus on LA effects in } \\
\text { AFG and authors draw conclusions from studies } \\
\text { that do not focus on the use and effects of LAs }\end{array}$ \\
\hline $\begin{array}{l}\text { Shoshani et } \\
\text { al. } 2005[6]\end{array}$ & $\begin{array}{l}\text { Lidocaine } \\
\text { Adrenaline }\end{array}$ & $\begin{array}{l}\text { In vivo (nude } \\
\text { mice) }\end{array}$ & $\begin{array}{l}\text { Adipose tissue from a } \\
\text { healthy human patient } \\
\text { undergoing elective } \\
\text { surgery, and grafted into } \\
\text { nude mice }\end{array}$ & $\begin{array}{l}\text { Lidocaine and adrenaline do not } \\
\text { have any influence on the take of } \\
\text { fat grafts or adipocyte viability after } \\
\text { lipotransfer in nude mice }\end{array}$ & $\begin{array}{l}\text { This is the first in vivo study related to lidocaine } \\
\text { and adrenaline effects } \\
\text { However, this interesting study includes a } \\
\text { centrifugation step that may be essential to } \\
\text { preserve the cells }\end{array}$ \\
\hline $\begin{array}{l}\text { Keck et al. } \\
2009[7]\end{array}$ & $\begin{array}{l}\text { - Lidocaine } 1 \% \\
\text { - Articaine } 1 \%+ \\
\text { epinephrine } 1: 200,000 \\
\text { - Ropivacaine } 0.75 \% \\
\text { - Prilocaine } 1 \% \\
\text { - Tumescent solution } \\
\text { (sodium chloride } 0.9 \% \\
+25 \mathrm{~mL} \\
\text { Articaine } 1 \%+ \\
\text { epinephrine } 1: 200,000+ \\
25 \mathrm{~mL} \text { bicarbonate) }\end{array}$ & In vitro & $\begin{array}{l}\text { Human preadipocytes in } \\
\text { culture (obtained after } \\
\text { collagenase digestion } \\
\text { of adipose tissue, from } \\
\text { abdominoplasties) }\end{array}$ & $\begin{array}{l}\text { All the tested LAs exert cytotoxic } \\
\text { effects } \\
\text { The tumescent solution used (with } \\
\text { diluted articaine) appears to be safe }\end{array}$ & $\begin{array}{l}\text { Incubation time of } 30 \text { min is less but very high } \\
\text { doses of LAs are directly applied on the isolated } \\
\text { cells, which explains the terrible cytotoxic effect }\end{array}$ \\
\hline $\begin{array}{l}\text { Keck et al. } \\
2010[8]\end{array}$ & $\begin{array}{l}\text { - Bupivacaine } 1 \% \\
\text { - Mepivacaine } 1 \% \\
\text { - Ropivacaine } 0.5 \% \\
\text { - Articaine } 4 \%+ \\
\text { epinephrine } 1: 100,000 \\
\text { - Lidocaine } 2 \%\end{array}$ & In vitro & $\begin{array}{l}\text { Human preadipocytes in } \\
\text { culture }\end{array}$ & $\begin{array}{l}\text { All LAs exert cytotoxic effects, } \\
\text { to various degrees (articaine + } \\
\text { epinephrine is the worst) } \\
\text { All LAs significantly impaired } \\
\text { the ability of preadipocytes to } \\
\text { differentiate into adipocytes }\end{array}$ & $\begin{array}{l}\text { Cells have been let in culture for } 24 \text { or } 48 \\
\text { h before being trypsinized, centrifuged and } \\
\text { resuspended directly in the different high } \\
\text { concentrated LAs. This explains the high level } \\
\text { of cytotoxicity }\end{array}$ \\
\hline $\begin{array}{l}\text { Keck et al. } \\
2012 \text { [87] }\end{array}$ & Lidocaine $2 \%$ & In vitro & $\begin{array}{l}\text { Human preadipocytes in } \\
\text { culture }\end{array}$ & $\begin{array}{l}\text { Lidocaine induces necrosis but } \\
\text { not apoptosis on preadipocytes. } \\
\text { Necrotic effect of lidocaine cannot be } \\
\text { prevented by coenzyme Q10. }\end{array}$ & The dose of lidocaine used is still very high \\
\hline $\begin{array}{l}\text { Sazaki } 2011 \\
{[88]}\end{array}$ & $\begin{array}{l}\text { Tumescent lidocaine } \\
(10.5-20 \mathrm{mg} / \mathrm{kg})\end{array}$ & Case report & Human adipocytes & $\begin{array}{l}\text { The amount of instilled tumescent } \\
\text { fluid and lidocaine dosage seem to } \\
\text { be safe for water-assisted liposuction }\end{array}$ & $\begin{array}{l}\text { This study focuses on water-assisted } \\
\text { liposuction and does not compare with and } \\
\text { without LA }\end{array}$ \\
\hline $\begin{array}{l}\text { Livaoglu et } \\
\text { al. } 2012 \text { [9] }\end{array}$ & $\begin{array}{l}\text { Lidocaine + epinephrine } \\
\text { Prilocaine }\end{array}$ & $\begin{array}{l}\text { In vivo (rat } \\
\text { model of } \\
\text { AFG with fat } \\
\text { from rat) }\end{array}$ & $\begin{array}{l}\text { Adipose tissue from rat } \\
\text { grafted for } 30 \text { and } 180 \\
\text { days }\end{array}$ & $\begin{array}{l}\text { Lidocaine plus epinephrine or } \\
\text { prilocaine have no negative effect } \\
\text { on microangiogenesis and fat graft } \\
\text { survival }\end{array}$ & $\begin{array}{l}\text { Fat was not from human lipoaspirates but was } \\
\text { excised from rats (from inguinal region) } \\
\text { Histologic findings are questionable }\end{array}$ \\
\hline $\begin{array}{l}\text { Girard et al. } \\
2013[10]\end{array}$ & $\begin{array}{l}\text { Lidocaine }(0.4 \text { to } 1.6 \\
\mathrm{mg} / \mathrm{mL}) \\
\pm \text { adrenaline }(1: 1000000)\end{array}$ & In vitro & $\begin{array}{l}\text { Human adipose-derived } \\
\text { stem cells (ADSCs) in } \\
\text { primary culture for few } \\
\text { days ( } 4 \text { days without any } \\
\text { passage) }\end{array}$ & $\begin{array}{l}\text { Lidocaine affects ADSC viability (but } \\
\text { no apoptosis) } \\
\text { Adrenaline has no effect } \\
\text { Lidocaine cytotoxicity can be partly } \\
\text { avoided by washing } \\
\text { Lidocaine may have anti- } \\
\text { inflammatory properties }\end{array}$ & $\begin{array}{l}\text { First authors in vitro study regarding lidocaine } \\
\text { effects } \\
\text { In vivo effects have to be confirmed } \\
\text { Clinical doses of lidocaine have been used }\end{array}$ \\
\hline $\begin{array}{l}\text { Atlan et al. } \\
(2012)[74]\end{array}$ & $\begin{array}{l}\text { Lidocaine ( } 0.4 \text { to } 1.6 \\
\mathrm{mg} / \mathrm{mL}) \\
\text { Ropivacaine }(0.4 \text { to } 1.6 \\
\mathrm{mg} / \mathrm{mL}) \\
\pm \text { adrenaline }(1: 1000000)\end{array}$ & In vitro & $\begin{array}{l}\text { Human adipose-derived } \\
\text { stem cells (ADSCs) in } \\
\text { primary culture for } 4 \text { days } \\
\text { (no passage) }\end{array}$ & $\begin{array}{l}\text { Ropivacaine is more cytotoxic than } \\
\text { lidocaine }\end{array}$ & $\begin{array}{l}\text { Ropivacaine and lidocaine have been tested } \\
\text { at equal doses, which represent high dose for } \\
\text { ropivacaine }\end{array}$ \\
\hline $\begin{array}{l}\text { Girard et al. } \\
2013[75]\end{array}$ & $\begin{array}{l}\text { Tumescent lidocaine }(0.8 \\
\mathrm{mg} / \mathrm{mL}) \\
+ \text { adrenaline }(1: 1000000)\end{array}$ & $\begin{array}{l}\text { In vivo } \\
\text { (mouse } \\
\text { model with } \\
\text { fat from } \\
\text { human } \\
\text { patient) }\end{array}$ & $\begin{array}{l}\text { Adipose tissue from } \\
\text { human patient (injected } \\
\text { into immunodeficient } \\
\text { mice) }\end{array}$ & $\begin{array}{l}\text { After } 1 \text { month of fat grafting, } \\
\text { histologic studies reveal that } \\
\text { lidocaine infiltrated at the fat harvest } \\
\text { site gives worst results compared to } \\
\text { tumescent solution without lidocaine } \\
\text { Prior to adipose tissue injection, at } \\
\text { least } 2 \text { washes with soft and short } \\
\text { centrifugations allow to improve graft } \\
\text { quality (better organization, more } \\
\text { stromal cells) }\end{array}$ & $\begin{array}{l}\text { This in vivo study completes the previous } \\
\text { in vitro studies from authors. Comparison is } \\
\text { done from a same patient: adipose tissue } \\
\text { was harvested on one side without lidocaine } \\
\text { (tumescent adrenaline), and on the other side } \\
\text { with a currently used tumescent solution with } \\
\text { lidocaine + adrenaline }\end{array}$ \\
\hline
\end{tabular}

Table 2: Studies reporting LA effects in AFG. 
by enabling vascularization of the graft (thus assuring cell survival) and enabling adipose tissue regeneration within the graft (thus assuring graft volume retention). ADSCs are also known to secrete growth factors and exert trophic effects that may contribute to surrounding tissue regeneration $[34,38,43]$.

Therefore, ADSC survival inside adipose grafts may improve considerably the quality of the graft, so it is of great importance to limit LA adverse effects during AFG.

\section{How to limit LA effects in AFG: Recommendations}

First of all, when fat is used for lipofilling, it is better not to use local anesthesia for liposuction if the surgery is performed under general anesthesia. Indeed, the use of a tumescent solution containing diluted epinephrine is recommended but there is no need of LA administration under general anesthesia. However, in order to ensure post-operative patient comfort, tumescent LA infiltration can be preformed after adipose tissue harvest for AFG.

Then, under local anesthesia alone, simple techniques as centrifugation and washing have been tested in order to get rid of LA deleterious effect. But alike controversies about LA effects in AFG, controversies also exist on centrifugation and washing effects.

Smith et al. did not find any advantages using centrifugation and washing and advised minimal manipulation of adipose tissue [76]. While positive aspect of washing have been highlighted in [77], the same authors found that decantation was better than strong centrifugation which could lead to loss of ADSCs, falling to the bottom of the tube as a cell pellet [78].

From our own studies, concerning centrifugation, adipose cell death is correlated to centrifugation speed and time, but cell death remains low below $400 \mathrm{~g}$ [79]. Liquid removal (containing LA and epinephrine) is also correlated to centrifugation speed and time, but there is no statistical difference between $400 \mathrm{~g}$ and $900 \mathrm{~g}$. Thus, knowing that strong centrifugation has already been reported as a cause of adipose tissue and ADSC damage [78,80,81], soft centrifugation at 400 $\mathrm{g}(1 \mathrm{~min}$ maximum $)$ represents a good compromise.

About washing, Alexander described its effect on adipose tissue by measuring lidocaine remnants [82]. He draws the conclusion that washing allows to remove a part of lidocaine infiltrated in adipose tissue, and he advised at least 2 wash in order to remove most of the drug. But washing steps alone are not sufficient as he could still observe some remnants of the drug. Thus, our combined studies [10,79] allow to define a protocol combining washing (at least 2) and soft centrifugations which clearly improve extraction of remnant liquids, thus removing LA.

In addition, this protocol encourages the presence of stromal cells and a large network of conjunctive tissue inside the graft. These cells are indeed capable of synthesizing collagen fibers and could be involved in neo vascularization of the graft, and therefore in its survival. Finally, this procedure of adipose tissue/lipoaspirate handling enhances graft survival by elimination of deleterious elements, among which local anesthetics, by a non-traumatic protocol involving washings and soft centrifugations (100 g/1 sec, to $400 \mathrm{~g} / 1 \mathrm{~min})[74,75]$.

Actually, it is difficult to compare methods if they have not been made in the same way. This can explain differences observed between studies. Results are mostly from in vitro studies in which too high speed centrifugation is used. Moreover, we have to keep in mind that adipose stem cells are essential for the survival of adipose tissue, and that LAs have a negative effect on these stem cells. Thus, our results, combined with those of other teams, tend to prove that it is necessary to wash the tissue at least two times, with short centrifugation at low speed, in order to obtain better results in fat grafting.

\section{Conclusion}

Before imagining overly complex methods to improve AFG (such as the use of bioscaffolds, growth factors...), it is first better to focus on simple ways to maximize cell survival upstream. Since there is so far no consensus on adipose tissue handling, it is still interesting to refine the protocol for adipose tissue harvest and handling.

To summarize, here are the principle recommendations regarding LA use in AFG:

- The use of LA should be avoided under general anesthesia (tumescent solution with diluted epinephrine but without LA is recommended)

- Under local anesthesia, infiltration of a tumescent solution containing diluted lidocaine and epinephrine is preferred

- Maximal dose of tumescent lidocaine is $35 \mathrm{mg} / \mathrm{kg}$ (or $30 \mathrm{mg} / \mathrm{kg}$ in France) to avoid systemic toxicity

- But lidocaine concentration should be as low as possible (below $0.8 \mathrm{mg} / \mathrm{mL}$ and even less) to avoid excessive cytotoxicity inside adipose graft

- Soft and short centrifugations with short washing steps should be included in adipose tissue handling prior to its injection, in order to get rid of infiltrated drugs.

Obviously, these recommendations should also be considered in the context of regenerative medicine when using ADSCs extracted from lipoaspirates.

\section{Acknowledgements}

We are grateful to the plastic surgeons: Atlan M, Delarue $\mathrm{P}$ and Hulard $\mathrm{O}$, who took part in this study by giving advice and allowed the collection of subcutaneous adipose tissue samples for our own experimental studies. We would also like to thank the group Clinifutur from Reunion Island, and French Ministry of National Education and Research financial support.

\section{References}

1. Coleman SR (2006) Facial augmentation with structural fat grafting. Clin Plas Surg 33: 567-577.

2. Coleman S (2004) Structural fat grafting. St. Louis, Mo.: Quality Medical Pub.

3. Shiffman MA (2010) Autologous fat transfer : Art, science, and Clinical Practice. Berlin: Springer.

4. Gir P, Brown SA, Oni G, Kashefi N, Mojallal A, et al. (2012) Fat grafting evidence-based review on autologous fat harvesting, processing, reinjection, and storage. Plast Reconstr Surg 130: 249-258.

5. Choi JH, Gimble JM, Lee K, Marra KG, Rubin JP, et al. (2010) Adipose tissue engineering for soft tissue regeneration. Tissue Eng Part B Rev 16: 413-426.

6. Shoshani O, Berger J, Fodor L, Ramon Y, Shupak A, et al. (2005) The effect of lidocaine and adrenaline on the viability of injected adipose tissue--an experimental study in nude mice. J Drugs Dermatol 4: 311-316.

7. Keck M, Janke J, Ueberreiter K (2009) Viability of preadipocytes in vitro: the influence of local anesthetics and pH. Dermatol Surg 35: 1251-1257.

8. Keck M, Zeyda M, Gollinger K, Burjak S, Kamolz LP, et al. (2010) Local anesthetics have a major impact on viability of preadipocytes and their differentiation into adipocytes. Plast Reconstr Surg 126: 1500-1505.

9. Livaoğlu M, Buruk CK, Uraloğlu M, Ersöz S, Livaogğlu A, et al. (2012) Effects of lidocaine plus epinephrine and prilocaine on autologous fat graft survival. Craniofac Surg 23: 1015-1018.

10. Girard AC, Atlan M, Bencharif K, Gunasekaran MK, Delarue P, et al. (2013) 
New insights into lidocaine and adrenaline effects on human adipose stem cells. Aesthetic Plast Surg 37: 144-152.

11. Sommer B, Sattler G (2000) Current concepts of fat graft survival: histology of aspirated adipose tissue and review of the literature. Dermatol Surg 26: 11591166

12. Henry SL, Bensley JG, Wood-Bradley RJ, Cullen-McEwen LA, Bertram JF, et al. (2012) White adipocytes: more than just fat depots. Int J Biochem Cell Biol 44: $435-440$.

13. Wronska A, Kmiec Z (2012) Structural and biochemical characteristics of various white adipose tissue depots. Acta Physiol (Oxf) 205: 194-208.

14. Zuk PA, Zhu M, Mizuno H, Huang J, Futrell JW, et al. (2001) Multilineage cells from human adipose tissue: implications for cell-based therapies. Tissue Eng 7: 211-228.

15. Zuk PA, Zhu M, Ashjian P, De Ugarte DA, Huang JI, et al. (2002) Human adipose tissue is a source of multipotent stem cells. Mol Biol Cell 13: 42794295.

16. Sen A, Lea-Currie YR, Sujkowska D, Franklin DM, Wilkison WO, et al. (2001) Adipogenic potential of human adipose derived stromal cells from multiple donors is heterogeneous. J Cell Biochem 81: 312-319.

17. Levi B, James AW, Glotzbach JP, Wan DC, Commons GW, et al. (2010) Depotspecific variation in the osteogenic and adipogenic potential of human adiposederived stromal cells. Plast Reconstr Surg 126: 822-834.

18. Rada T, Reis RL, Gomes ME (2011) Distinct stem cells subpopulations isolated from human adipose tissue exhibit different chondrogenic and osteogenic differentiation potential. Stem Cell Rev 7: 64-76.

19. Guilak F, Awad HA, Fermor B, Leddy HA, Gimble JM (2004) Adipose-derived adult stem cells for cartilage tissue engineering. Biorheology 41: 389-399.

20. Ogawa R, Mizuno H, Watanabe A, Migita M, Shimada T, et al. (2004) Osteogenic and chondrogenic differentiation by adipose-derived stem cells harvested from GFP transgenic mice. Biochem Biophys Res Commun 313: 871-877.

21. Awad HA, Wickham MQ, Leddy HA, Gimble JM, Guilak F (2004) Chondrogenic differentiation of adipose-derived adult stem cells in agarose, alginate, and gelatin scaffolds. Biomaterials 25: 3211-3222.

22. Kim HJ, Park SH, Durham J, Gimble JM, Kaplan DL, et al. (2012) In vitro chondrogenic differentiation of human adipose-derived stem cells with silk scaffolds. J Tissue Eng 3: 2041731412466405.

23. Hattori H, Sato M, Masuoka K, Ishihara M, Kikuchi T, et al. (2004) Osteogenic potential of human adipose tissue-derived stromal cells as an alternative stem cell source. Cells Tissues Organs 178: 2-12.

24. Yoon E, Dhar S, Chun DE, Gharibjanian NA, Evans GR (2007) In vivo osteogenic potential of human adipose-derived stem cells/poly lactide-coglycolic acid constructs for bone regeneration in a rat critical-sized calvarial defect model. Tissue Eng 13: 619-627.

25. Hicok KC, Du Laney TV, Zhou YS, Halvorsen YD, Hitt DC, et al. (2004) Human adipose-derived adult stem cells produce osteoid in vivo. Tissue Eng 10: 371 380.

26. Weinzierl K, Hemprich A, Frerich B (2006) Bone engineering with adipose tissue derived stromal cells. J Craniomaxillofac Surg 34: 466-471.

27. Raabe O, Shell K, Fietz D, Freitag C, Ohrndorf A, et al. (2013) Tenogenic differentiation of equine adipose-tissue-derived stem cells under the influence of tensile strain, growth differentiation factors and various oxygen tensions. Cell Tissue Res 352: 509-521.

28. Gimble JM, Guilak F, Nuttall ME, Sathishkumar S, Vidal M, et al. (2008) In vitro Differentiation Potential of Mesenchymal Stem Cells. Transfus Med Hemother 35: 228-238.

29. Di Rocco G, lachininoto MG, Tritarelli A, Straino S, Zacheo A, et al. (2006) Myogenic potential of adipose-tissue-derived cells. J Cell Sci 119: 2945-2952.

30. Yang D, Wang W, Li L, Peng Y, Chen P, et al. (2013) The relative contribution of paracine effect versus direct differentiation on adipose-derived stem cell transplantation mediated cardiac repair. PLoS One 8: e59020.

31. Cardozo AJ, Gómez DE, Argibay PF (2012) Neurogenic differentiation of human adipose-derived stem cells: relevance of different signaling molecules, transcription factors, and key marker genes. Gene 511: 427-436.
32. Gimble JM, Bunnell BA, Guilak F (2012) Human adipose-derived cells: an update on the transition to clinical translation. Regen Med 7: 225-235.

33. Gimble JM, Katz AJ, Bunnell BA (2007) Adipose-derived stem cells for regenerative medicine. Circ Res 100: 1249-1260.

34. Coleman SR (2006) Structural fat grafting: more than a permanent filler. Plast Reconstr Surg 118: 108S-120S.

35. Moseley TA, Zhu M, Hedrick MH (2006) Adipose-derived stem and progenitor cells as fillers in plastic and reconstructive surgery. Plast Reconstr Surg 118 121S-128S.

36. Tabit CJ, Slack GC, Fan K, Wan DC, Bradley JP (2012) Fat grafting versus adipose-derived stem cell therapy: distinguishing indications, techniques, and outcomes. Aesthetic Plast Surg 36: 704-713.

37. Matsumoto D, Sato K, Gonda K, Takaki Y, Shigeura T, et al. (2006) Cellassisted lipotransfer: supportive use of human adipose-derived cells for sof tissue augmentation with lipoinjection. Tissue Eng 12: 3375-3382.

38. Zhu M, Zhou Z, Chen Y, Schreiber R, Ransom JT, et al. (2010) Supplementation of fat grafts with adipose-derived regenerative cells improves long-term graft retention. Ann Plast Surg 64: 222-228.

39. Trojahn Kølle SF, Oliveri RS, Glovinski PV, Elberg JJ, Fischer-Nielsen A, et al. (2012) Importance of mesenchymal stem cells in autologous fat grafting: a systematic review of existing studies. J Plast Surg Hand Surg 46: 59-68.

40. Philips BJ, Marra KG, Rubin JP (2012) Adipose stem cell-based soft tissue regeneration. Expert Opin Biol Ther 12: 155-163.

41. Suga $H$, Eto $H$, Aoi N, Kato H, Araki J, et al. (2010) Adipose tissue remodeling under ischemia: death of adipocytes and activation of stem/progenitor cells Plast Reconstr Surg 126: 1911-1923.

42. Yoshimura K, Suga $\mathrm{H}$, Eto $\mathrm{H}$ (2009) Adipose-derived stem/progenitor cells: roles in adipose tissue remodeling and potential use for soft tissue augmentation. Regen Med 4: 265-273.

43. Yoshimura K, Eto $\mathrm{H}$, Kato $\mathrm{H}$, Doi K, Aoi $\mathrm{N}$ (2011) In vivo manipulation of stem cells for adipose tissue repair/reconstruction. Regen Med 6: 33-41.

44. Shiffman M (2010) History of Autologous Fat Transfer. In M. A. Shiffman, Autologous Fat Transfer: Springer Berlin Heidelberg.

45. Klein JA (1990) The tumescent technique. Anesthesia and modified liposuction technique. Dermatol Clin 8: 425-437.

46. Sterodimas A, Boriani F, Magarakis E, Nicaretta B, Pereira LH, et al. (2012) Thirtyfour years of liposuction: past, present and future. Eur Rev Med Pharmacol Sci 16: 393-406.

47. Illouz YG (1988) Present results of fat injection. Aesthetic Plast Surg 12: 175 181

48. Bircoll M, Novack BH (1987) Autologous fat transplantation employing liposuction techniques. Ann Plast Surg 18: 327-329.

49. Klein JA (1990) Tumescent technique for regional anesthesia permits lidocaine doses of $35 \mathrm{mg} / \mathrm{kg}$ for liposuction. J Dermatol Surg Oncol 16: 248-263.

50. Hanke CW, Bernstein G, Bullock S (1995) Safety of tumescent liposuction in 15,336 patients. National survey results. Dermatol Surg 21: 459-462.

51. Coleman WP 3rd, Klein JA (1992) Use of the tumescent technique for scalp surgery, dermabrasion, and soft tissue reconstruction. J Dermatol Surg Oncol 18: $130-135$.

52. Cummins TR (2007) Setting up for the block: the mechanism underlying lidocaine's use-dependent inhibition of sodium channels. J Physiol 582: 11.

53. Butterworth JF 4th, Strichartz GR (1990) Molecular mechanisms of local anesthesia: a review. Anesthesiology 72: 711-734.

54. McLure HA, Rubin AP (2005) Review of local anaesthetic agents. Minerva Anestesiol 71: 59-74

55. Hagerty T, Klein $P$ (1999) Fat partitioning of lidocaine in tumescent liposuction. Ann Plast Surg 42: 372-375.

56. Bernards CM, Kopacz DJ (1999) Effect of epinephrine on lidocaine clearance in vivo: a microdialysis study in humans. Anesthesiology 91: 962-968.

57. Rosenberg PH, Veering BT, Urmey WF (2004) Maximum recommended doses of local anesthetics: a multifactorial concept. Reg Anesth Pain Med 29: 564 575 
58. Klein JA, Kassarjdian N (1997) Lidocaine toxicity with tumescent liposuction. A case report of probable drug interactions. Dermatol Surg 23: 1169-1174.

59. Swanson E (2012) Prospective study of lidocaine, bupivacaine, and epinephrine levels and blood loss in patients undergoing liposuction and abdominoplasty. Plast Reconstr Surg 130: 702-722.

60. Tucker GT (1986) Pharmacokinetics of local anaesthetics. Br J Anaesth 58 717-731.

61. Failey CL, Vemula R, Borah GL, Hsia HC (2009) Intraoperative use of bupivacaine for tumescent liposuction: the Robert Wood Johnson experience. Plast Reconstr Surg 124: 1304-1311.

62. Lindenblatt N, Belusa L, Tiefenbach B, Schareck W, Olbrisch RR (2004) Prilocaine plasma levels and methemoglobinemia in patients undergoing tumescent liposuction involving less than 2,000 ml. Aesthetic Plast Surg 28: $435-440$.

63. Kaufman MR, Bradley JP, Dickinson B, Heller JB, Wasson K, et al. (2007) Autologous fat transfer national consensus survey: trends in techniques for harvest, preparation, and application, and perception of short- and long-term results. Plast Reconstr Surg 119: 323-331.

64. Shiffman MA, Di Giuseppe A (2006) Liposuction : principles and practice. New York: Springer

65. Grossmann M, Sattler G, Pistner H, Oertel R, Richter K, et al. (2004) Pharmacokinetics of articaine hydrochloride in tumescent local anesthesia for liposuction. J Clin Pharmacol 44: 1282-1289.

66. Klein JA (1998) Intravenous fluids and bupivacaine are contraindicated in tumescent liposuction. Plast Reconstr Surg 102: 2516-2519.

67. Perez-Castro R, Patel S, Garavito-Aguilar ZV, Rosenberg A, Recio-Pinto E et al. (2009) Cytotoxicity of local anesthetics in human neuronal cells. Anesth Analg 108: 997-1007.

68. Fedder C, Beck-Schimmer B, Aguirre J, Hasler M, Roth-Z'graggen B, et al. (2010) In vitro exposure of human fibroblasts to local anaesthetics impairs cell growth. Clin Exp Immunol 162: 280-288.

69. Grishko V, Xu M, Wilson G, Pearsall AW 4th (2010) Apoptosis and mitochondrial dysfunction in human chondrocytes following exposure to lidocaine, bupivacaine, and ropivacaine. J Bone Joint Surg Am 92: 609-618.

70. Maurice JM, Gan Y, Ma FX, Chang YC, Hibner M, et al. (2010) Bupivacaine causes cytotoxicity in mouse $\mathrm{C} 2 \mathrm{C} 12$ myoblast cells: involvement of ERK and Akt signaling pathways. Acta Pharmacol Sin 31: 493-500.

71. Chu CR, Coyle CH, Chu CT, Szczodry M, Seshadri V, et al. (2010) In vivo effects of single intra-articular injection of $0.5 \%$ bupivacaine on articular cartilage. J Bone Joint Surg Am 92: 599-608.

72. Townshend D, Emmerson K, Jones S, Partington P, Muller S (2009) Intraarticular injection versus portal infiltration of $0.5 \%$ bupivacaine following arthroscopy of the knee: a prospective, randomised double-blinded trial. J Bone Joint Surg Br 91: 601-603.

73. Bailie DS, Ellenbecker TS (2009) Severe chondrolysis after shoulder arthroscopy: a case series. J Shoulder Elbow Surg 18: 742-747.
74. Atlan M, Girard AC, Festy F, Roche R (2012) Influence de la lidocaïne et de la ropivacaïne sur le tissu adipeux et les cellules souches adipocytaires. SoFCPRE 2012, Paris.

75. Girard AC, Mirbeau S, Festy F, Roche R (2012) De la biología al injerto de grasa: como mejorar el lipofilling. SETGRA 2012, Madrid.

76. Smith P, Adams WP Jr, Lipschitz AH, Chau B, Sorokin E, et al. (2006) Autologous human fat grafting: effect of harvesting and preparation techniques on adipocyte graft survival. Plast Reconstr Surg 117: 1836-1844.

77. Condé-Green A, de Amorim NF, Pitanguy I (2010) Influence of decantation washing and centrifugation on adipocyte and mesenchymal stem cell content of aspirated adipose tissue: a comparative study. J Plast Reconstr Aesthet Surg 63: $1375-1381$

78. Condé-Green A, Baptista LS, de Amorin NF, de Oliveira ED, da Silva KR, et al. (2010) Effects of centrifugation on cell composition and viability of aspirated adipose tissue processed for transplantation. Aesthet Surg J 30: 249-255.

79. Hoareau L, Bencharif K, Girard AC, Gence L, Delarue P, et al. (2013) Effect of centrifugation and washing on adipose graft viability: a new method to improve graft efficiency. J Plast Reconstr Aesthet Surg 66: 712-719.

80. Kurita M, Matsumoto D, Shigeura T, Sato K, Gonda K, et al. (2008) Influences of centrifugation on cells and tissues in liposuction aspirates: optimized centrifugation for lipotransfer and cell isolation. Plast Reconstr Surg 121: 10331041.

81. Xie Y, Zheng D, Li Q, Chen Y, Lei H, et al. (2010) The effect of centrifugation on viability of fat grafts: an evaluation with the glucose transport test. J Plast Reconstr Aesthet Surg 63: 482-487.

82. Alexander RW (2010) Autologous fat grafting: a study of residual intracellular adipocyte lidocaine. Autologous Fat Transfer. In M. A. Shiffman, Springer Berlin Heidelberg,445-450.

83. Stoelting RK, Hillier S (2006) Handbook of pharmacology \& physiology in anesthetic practice, Philadelphia: Lippincott Williams \& Wilkins.

84. Malamed SF (2013) Handbook of local anesthesia, 6th Ed. St. Louis: Elsevier/ Mosby.

85. Moore JH Jr, Kolaczynski JW, Morales LM, Considine RV, Pietrzkowski Z, et al. (1995) Viability of fat obtained by syringe suction lipectomy: effects of local anesthesia with lidocaine. Aesthetic Plast Surg 19: 335-339.

86. Large V, Reynisdottir S, Eleborg L, van Harmelen V, Strömmer L, et al. (1997) Lipolysis in human fat cells obtained under local and general anesthesia. Int J Obes Relat Metab Disord 21: 78-82.

87. Keck M, Zeyda M, Burjak S, Kamolz LP, Selig H, et al. (2012) Coenzyme Q10 does not enhance preadipocyte viability in an in vitro lipotransfer model. Aesthetic Plast Surg 36: 453-457.

88. Sasaki GH (2011) Water-assisted liposuction for body contouring and lipoharvesting: safety and efficacy in 41 consecutive patients. Aesthet Surg J 31: 76-88 